\title{
DETERMINATION OF THE COMPOSITION AND CONTAMINATION WITH HEAVY METALS OF SOILS FROM THE SREBARNA LAKE RESERVE
}

\author{
METODI MLADENOV ${ }^{\mathrm{a}}$, SPASKA YANEVA ${ }^{\mathrm{b}}$
}

\begin{abstract}
The wetlands in direct contact with large rivers, such as the connection between Srebarna Lake and the Danube River, are particularly vulnerable to heavy metals. These metals can be a serious problem due to their toxicity, long persistence and bioaccumulation in the food chain, at the top of which in the wetlands are the waterfowl. For this reason, they are extremely susceptible to the accumulation and influence of heavy metals in their bodies and it is possible to come on to accumulation of significant concentrations, leading to negative effects for them. In this regard, subjects of study in this article are soils from the reserve area. Eight soil samples were tested for $\mathrm{pH}$, electrical conductivity, nutrient content and heavy metals presence. The presented results show that the soils in the area have a relatively good stock in terms of carbon (humus), $\mathrm{Ca}, \mathrm{Mg}, \mathrm{K}$ and $\mathrm{P}$, and although some heavy metals and metalloids have been found, their concentrations are below the permissible normatively established values.
\end{abstract}

Keywords: soil composition, bioaccumulations, nutrients, heavy metals, contamination, toxicity.

\section{INTRODUCTION}

Srebarna Lake is situated in northeastern Bulgaria, on the Bulgarian bank of the Danube, beside the village of Srebarna [1, 2]. It has coordinates: $44^{\circ} 07 \mathrm{~N}, 27^{\circ} 04 \mathrm{E}$, area of 120 ha, a depth of 1.7 to $4.7 \mathrm{~m}$ dependent on Danube water level, volume of $2.81-14.35 \mathrm{~km}^{3}$ and the lake status is euhypertrophic [3]. "Srebarna" nature reserve is one of the eleven wetlands in

\footnotetext{
a University of Chemical Technology and Metallurgy, Department of Engineering Ecology, 8 St. KI. Ohridski Bul, 1756, Sofia, Bulgaria.

b University of Chemical Technology and Metallurgy, Department of Organic Chemical Technology, 8 St. KI. Ohridski Bul, 1756, Sofia, Bulgaria.

*Corresponding author: mladenov@uctm.edu
} 
Bulgaria, declared in 1942 like a "breeding ground" for waterfowl, and hunting in the lake was forbidden. Over the years, "Srebarna" has had undergone many changes in its status, mainly due to the different attitude of the state to its management - from inclusion in the list of endangered from strike off the UNESCO list, to granting the status of a maintained reserve and its inclusion for permanent in the list of the sites of the world cultural and natural heritage. $[4,5]$.

Wetlands such as Srebarna Lake are areas where water covers the soil or is present in its surface layer, year-round or seasonally. In these ecosystems, water is the main factor on which ecological conditions and related animal and plant species depend [6]. Periodic monitoring of various environmental factors and the interrelationships between them is crucial for the maintenance of ecological status and biodiversity, as the accumulation of pollutants in these ecosystems can lead to deterioration of biological living conditions and to the disruption of ecological equilibrium [7-11]. The wetlands in direct contact with large rivers, such as the connection between Srebarna Lake and the Danube River, are particularly vulnerable to heavy metals. In such type of wetland, the assessment of heavy metal content gives a more realistic idea of the actual impact of the river on the surrounding environment, as these river waters are usually severely affected by human activity [12-15].

Heavy metals, can be a serious problem due to their toxicity, long persistence and bioaccumulation in the food chain, and in high concentrations can lead to damage to animal species. They have the ability to react with the aquatic ecosystems with multiple and complex mechanisms and interactions, and can bind to different geochemical phases in sediments. They can also accumulate in the aquatic biota and have the ability to be converted into organic complexes, which may be more toxic than the simple elements. Accumulation and movement in aquatic ecosystems, when the concentration of heavy metals in the water is low, can occur along the food chain, in base of which are the soil and sediment. $[11,13,14,16]$.

Because waterfowl have a relatively long life and are at the top of the food chain in marshy systems, they are extremely susceptible to the accumulation and influence of heavy metals in their bodies. In migratory birds, even short-term contact with contaminated habitat leads to the accumulation in the body of significant amounts of the respective pollutant, which is directly related to their rapid metabolism, and it is possible to lead to the accumulation of significant concentrations leading to negative effects for them [17]. Thus, for example, Kwok and team [18] reported the bioaccumulation of nonessential elements $(\mathrm{Cd}, \mathrm{Hg}, \mathrm{Pb})$ in various organs and tissues of Ardeid, such as feathers, liver, kidneys, muscle and eggs, such as claim some of these inorganic elements can accumulate in the egg shells, and that these shells 
can be used as indicators of heavy metal contamination. The following figure summarizes the main heavy metals that are monitored in the environment and some of the negative effects they have on the bird population.

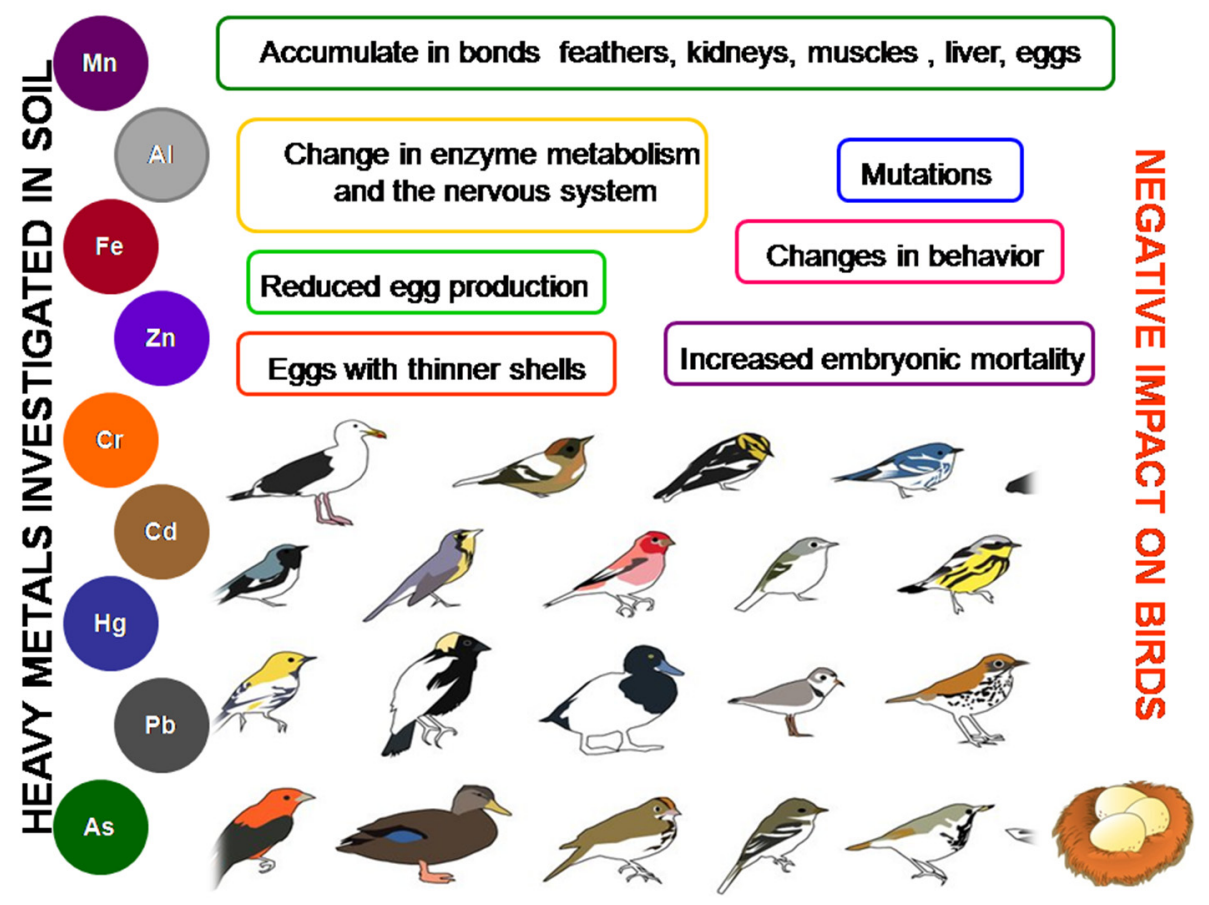

Figure 1. Accumulation of heavy metals in the avian organisms

The objectives of this study are to survey the soil composition and heavy metals content in the Srebarna Lake wetland.

\section{RESULTS AND DISCUSSION}

The reaction of soils has a significant impact on the soil formation process and on soil fertility. The vital activity of microorganisms, the direction of the ongoing biochemical processes in the soil and the availability of nutrients for plants depend to a large extent on it. The most favorable for the plants are the weakly acidic and neutral reaction of the soil, and in the conditions of low $\mathrm{pH}$ the solubility and migration of some of the elements significantly increase. 
The established values for $\mathrm{pH}$ of all samples (see Table 1) are in the range $\mathrm{pH}=6.2-7.2$, which defines them as extremely favorable for the development of plant species, and the established values correspond to the data on soil acidity in wetlands. The lowest established value is for sample 6 $\mathrm{pH}=6.28$, and the highest for sample $5-\mathrm{pH}=7.11$.

Table 1. Physicochemical parameters

\begin{tabular}{|c|c|c|}
\hline Sample № & $\mathbf{p H}$ & Conductivity $\mathbf{( m S / c m )}$ \\
\hline 1 & 7.06 & $0.627 \pm 0.009$ \\
\hline 2 & 6.83 & $0.534 \pm 0.006$ \\
\hline 3 & 6.42 & $0.698 \pm 0.010$ \\
\hline 4 & 6.71 & $0.208 \pm 0.005$ \\
\hline 5 & 7.11 & $0.189 \pm 0.005$ \\
\hline 6 & 6.28 & $0.144 \pm 0.004$ \\
\hline 7 & 7.05 & $0.574 \pm 0.008$ \\
\hline 8 & 6.77 & $0.236 \pm 0.007$ \\
\hline
\end{tabular}

The determination of electrical conductivity is done in order to determine the presence of mobile forms (usually ions) of the elements in the solution and usually higher values of conductivity, indicate the presence of a large number of these mobile forms, mainly metals. The measured values for this indicator (see Table 1) characterize the studied soils as poor of mobile ions of the elements, as the highest values were found in samples 1 and 3 $0.627 \mathrm{mS} / \mathrm{cm}$ and $0.698 \mathrm{mS} / \mathrm{cm}$, respectively.

Plants obtain phosphorus from the soil, where it is found in the form of organic and mineral compounds in relatively small quantities - 0.05$0.25 \%$. The amount and distribution of phosphorus compounds in the soil depend mainly on the phosphorus content of the soil-forming rock and on the conditions of soil formation. The results with respect to this element (see Table 2) show a relatively good stock in the studied soils.

Table 2. Nutritional element content, in dry matter

\begin{tabular}{|c|c|c|c|c|c|c|c|}
\hline $\begin{array}{c}\text { Sample } \\
\text { № }\end{array}$ & $\boldsymbol{N}$ & $\boldsymbol{P}$ & $\boldsymbol{K}$ & $\boldsymbol{N a}$ & $\boldsymbol{C a}$ & $\boldsymbol{M g}$ & $\boldsymbol{C}^{*}$ \\
\cline { 2 - 8 } & $0.06 \pm 0.007$ & $0.20 \pm 0.01$ & $0.54 \pm 0.09$ & $0.063 \pm 0.011$ & $1.54 \pm 0.33$ & $0.84 \pm 0.10$ & $5.37 \pm 0.22$ \\
\hline 1 & $<0.01$ & $0.19 \pm 0.01$ & $0.56 \pm 0.08$ & $0.082 \pm 0.015$ & $1.47 \pm 0.28$ & $0.67 \pm 0.14$ & $2.13 \pm 0.18$ \\
\hline 2 & $0.01 \pm 0.004$ & $0.21 \pm 0.02$ & $0.75 \pm 0.09$ & $0.072 \pm 0.012$ & $0.74 \pm 0.17$ & $0.77 \pm 0.11$ & $3.61 \pm 0.15$ \\
\hline 3 & $<0.01$ & $0.14 \pm 0.01$ & $0.63 \pm 0.08$ & $0.173 \pm 0.022$ & $1.27 \pm 0.25$ & $1.24 \pm 0.17$ & $1.75 \pm 0.11$ \\
\hline 4 & $<0.01$ & $0.10 \pm 0.01$ & $0.42 \pm 0.07$ & $0.054 \pm 0.013$ & $2.32 \pm 0.34$ & $0.62 \pm 0.11$ & $2.54 \pm 0.19$ \\
\hline 5 & $0.02 \pm 0.004$ & $0.16 \pm 0.01$ & $0.70 \pm 0.09$ & $0.058 \pm 014$ & $2.73 \pm 0.37$ & $0.86 \pm 0.12$ & $1.17 \pm 0.16$ \\
\hline 6 & $<0.01$ & $0.17 \pm 0.01$ & $0.65 \pm 0.08$ & $0.068 \pm 0.013$ & $2.19 \pm 0.28$ & $0.58 \pm 0.09$ & $3.47 \pm 0.23$ \\
\hline 7 & $0.04 \pm 0.006$ & 0.17 & \\
\hline 8 & $<0.01$ & $0.15 \pm 0.02$ & $0.60 \pm 0.09$ & $0.073 \pm 0.015$ & $1.47 \pm 0.25$ & $0.93 \pm 0.14$ & $2.73 \pm 0.17$ \\
\hline
\end{tabular}

* expressed like a content of humus 
The carbon content in the soil is mostly in the form of the so-called humic compounds, because of that in practice it is accepted to determine the content of total carbon and most often this indicator of brevity is referred to as humus. The average humus content in the soils in Bulgaria is in the range of $2-4 \%$. The comparison of the obtained results (see Table 2) with these values again shows a good stock in the studied samples. Lowest, below $2 \%$ are the values established in samples: $4-1.75 \%$ and $6-1.17 \%$.

The results for the total content of the element nitrogen show extremely low values - below $0.1 \%$, in all samples.

The elements $\mathrm{Na}, \mathrm{Ka}, \mathrm{Ca}$ and $\mathrm{Mg}$ serve as a source of cationic nutrition for plants and belong to the group of so-called exchange cations. The results of their analysis show that the content of calcium cations is predominant a characteristic feature of the soils formed under grassy and forest vegetation. The highest content (Table 2) for this element was found in sample $6-2.73 \%$, and the lowest in sample $3-0.74 \%$.

The results for the sodium content in all samples are in the range of $0.05-0.2 \%$ and classify them as non-saline soils. Regarding the element $\mathrm{K}$, the results (see Table 2 ) fall in the range of $0.4-0.8 \%$ and show a good supply of this nutrient. For the element magnesium, the highest content was found in sample $4-1.24 \%$, and the lowest in sample $7-0.58 \%$.

The results of the analysis for heavy metal content performed by ICPOES are given in Table. 3 .

Table 3. Content of heavy metals, in dry matter

\begin{tabular}{|c|c|c|c|c|c|c|c|c|}
\hline $\begin{array}{c}\text { Concentration, } \\
\text { mg.kg-1 }^{-1}\end{array}$ & $\mathbf{1}$ & $\mathbf{2}$ & $\mathbf{3}$ & $\mathbf{4}$ & $\mathbf{5}$ & $\mathbf{6}$ & $\mathbf{7}$ & $\mathbf{8}$ \\
\cline { 2 - 9 } $\mathrm{Al}^{*} 10^{3}$ & 25.5 & 28.4 & 27.2 & 32.4 & 25.6 & 26.9 & 22.5 & 28.4 \\
\hline $\mathrm{Cr}$ & 50.1 & 57.7 & 52.6 & 74.7 & 53.6 & 44.2 & 47.8 & 56.6 \\
\hline $\mathrm{Mn}$ & 491.3 & 567.1 & 697.3 & 681.1 & 491.5 & 593.5 & 447.4 & 631.0 \\
\hline $\mathrm{Fe}^{*} 10^{3}$ & 11.3 & 22.9 & 30.2 & 25.6 & 20.4 & 16.3 & 18.0 & 17.4 \\
\hline $\mathrm{Co}$ & 9.8 & 10.2 & 10.7 & 14.3 & 12.8 & 11.4 & 11.1 & 12.2 \\
\hline $\mathrm{Ni}$ & 31.2 & 24.5 & 34.3 & 45.1 & 27.6 & 32.4 & 21.7 & 24.4 \\
\hline $\mathrm{Cu}$ & 33.4 & 50.2 & 56.3 & 63.3 & 28.4 & 33.2 & 30.7 & 37.2 \\
\hline $\mathrm{Zn}$ & 70.2 & 68.4 & 79.4 & 89.3 & 62.4 & 60.3 & 51.8 & 68.6 \\
\hline $\mathrm{As}$ & $<0.5$ & $<0.5$ & $<0.5$ & 11.7 & 5.11 & 1.97 & $<0.5$ & 3.5 \\
\hline $\mathrm{Pb}$ & $<0.5$ & $<0.5$ & $<0.5$ & 2.5 & 1.7 & $<0.5$ & $<0.5$ & $<0.5$ \\
\hline $\mathrm{Se}$ & $<0.5$ & $<0.5$ & $<0.5$ & $<0.5$ & $<0.5$ & $<0.5$ & $<0.5$ & $<0.5$ \\
\hline $\mathrm{Bi}$ & $<0.5$ & $<0.5$ & $<0.5$ & $<0.5$ & $<0.5$ & $<0.5$ & $<0.5$ & $<0.5$ \\
\hline $\mathrm{Cd}$ & $<0.25$ & $<0.25$ & $<0.25$ & $<0.25$ & $<0.25$ & $<0.25$ & $<0.25$ & $<0.25$ \\
\hline $\mathrm{Sb}$ & $<0.5$ & $<0.5$ & $<0.5$ & $<0.5$ & $<0.5$ & $<0.5$ & $<0.5$ & $<0.5$ \\
\hline
\end{tabular}

"Values for these elements showed with " $<$ " represent the detection limits values 
Obtained values for heavy metals contents were compared with maximum admissible concentrations (MAC) values for heavy metals in soils, for the elements for which such values are regulated in the Bulgarian legislation [19]. These values depend on the type of soil usage, the objects of preservation, the mechanical composition and $\mathrm{pH}\left(\mathrm{H}_{2} \mathrm{O}\right)$ of the soils. According to this regulation, the sampled soils can be classified like a permanent grass areas and the MAC values according to established $\mathrm{pH}$ values for them are presented in Table 4.

Table 4. MAC values for soils of permanent grass areas

\begin{tabular}{|c|c|c|c|c|c|c|}
\hline Element & $\mathrm{As}$ & $\mathrm{Cu}$ & $\mathrm{Cr}$ & $\mathrm{Ni}$ & $\mathrm{Pb}$ & $\mathrm{Zn}$ \\
\hline $\mathrm{MAC}$ at $\mathrm{pH}\left(\mathrm{H}_{2} \mathrm{O}\right)$ & 30 & 140 & 250 & 80 & 130 & 390 \\
$6.0-7.4, \mathrm{mg}^{-1} \mathrm{~kg}^{-1}$ & & & & & \\
\hline
\end{tabular}

The presence of $\mathrm{Al}, \mathrm{Co}, \mathrm{Cu}, \mathrm{Fe}, \mathrm{Zn}, \mathrm{Ni}, \mathrm{Mn}$ and $\mathrm{Cr}$ was detected in all tested samples (see Table 3), and highest values were found for the elements $\mathrm{Al}$ and $\mathrm{Fe}$ in the concentration ranges of $22000-32000 \mathrm{mg} \cdot \mathrm{kg}^{-1}$ and 11000-31000 mg. $\mathrm{kg}^{-1}$, respectively, for which elements, however, there are no MAC values in the national legislation. The data obtained from the study also show high contents of the element manganese - in the range of 400$700 \mathrm{mg} . \mathrm{kg}^{-1}$, for which, element also has no normative maximum values.

Significant contents were also found for the elements $\mathrm{Zn}$ and $\mathrm{Cr}$, although below the MAC values $\left(\mathrm{MAC}_{\mathrm{Zn}}=390 \mathrm{mg} \cdot \mathrm{kg}^{-1}\right.$ and $M A C_{\mathrm{Cr}}=250$ mg. $\mathrm{kg}^{-1}$ ), respectively for $\mathrm{Zn}-51-90 \mathrm{mg} \cdot \mathrm{kg}^{-1}$ and for $\mathrm{Cr}-44-75 \mathrm{mg} \cdot \mathrm{kg}^{-1}$. Arsenic content was found in samples 4, 5, 6 and 8, but in concentrations significantly lower than the corresponding MAC value $-30 \mathrm{mg} \cdot \mathrm{kg}^{-1}$.

No dependence of the content of the determined elements on the location of the sampling points is established. Such a dependence can be allowed for the element lead, for which values have been established above the limits of determination of the apparatus used, in two of the samples (sample $4-2.5 \mathrm{mg} \cdot \mathrm{kg}^{-1}$ and sample $5-1.7 \mathrm{mg} \cdot \mathrm{kg}^{-1}$ ) which are located not far from automobile road.

The results of the soil surveys show that they do not appear as a source of heavy metals for the environment in the reserve. The studied soils cannot lead to a negative impact on the bird populations inhabiting the territory of Srebarna Lake reserve. Due to the connection of the lake with the Danube River and the water regimes in which the areas around the reserve are flooded periodically, it is recommended to conduct annual monitoring of soil conditions for heavy metals and other toxic substances subject to different control and monitoring regimes. 
DETERMINATION OF THE COMPOSITION AND CONTAMINATION WITH HEAVY METALS OF SOILS FROM THE SREBARNA LAKE RESERVE

\section{CONCLUSIONS}

The established values for $\mathrm{pH}$ of all samples are in the range $\mathrm{pH}=$ 6.2-7.2, which defines them as extremely favorable for the development of plant species. The measured values for the conductivity characterize the studied soils as poor of mobile ions of the elements.

The analysis of the content of nutrients in the tested samples shows a relatively good stock in terms of carbon (humus), $\mathrm{Ca}, \mathrm{Mg}, \mathrm{K}$ and $\mathrm{P}$ and insufficient content of $\mathrm{N}$, and the values for the element sodium allow the studied soils to be classified as non-saline soils.

The results of the analysis of the content of heavy metals in the studied soil samples show values many times lower than the maximum permissible concentrations established in the national legislation.

\section{EXPERIMENTAL SECTION}

\section{Sampling and sample preparation}

Sampling points are situated in the area of Srebarna Lake reserve see Figure 2. The soil samples were taken in 2019 year, according to standard requirement [20]. The depth of sampling is $0-30 \mathrm{~cm}$. Preliminary treatment for preparation for physico-chemical tests was performed according to the requirements of [21]. The sample preparation of the samples for analysis of the content of $\mathrm{K}, \mathrm{Na}, \mathrm{Ca}$ and $\mathrm{Mg}$ and heavy metals was performed according to the standard methodology - BNS 16174 [22].

\section{Instrumentation and measurement conditions}

Conductivity measurements and $\mathrm{pH}$ determinations were performed with combined $\mathrm{pH}$ meter PCE-PHD1 (PCE instruments), accordint to requirements of - BNS EN 15933 [23] and BNS ISO 11265 [24]. The Kjeldahl method was used for determination of nitrogen content [25]. Phosphorus was determined spectrophotometric [26], through UV-VIS spectrophotometer Specol-11, Carle-Tseys (Germany). The content of $\mathrm{K}, \mathrm{Na}, \mathrm{Ca}$ and $\mathrm{Mg}$ was determinate by flame atomic-absorption spectrometry (Thermo Elemental, SOLAR - M5 AA) after decomposition in "aqua regia". Contents of the elements $\mathrm{Al}, \mathrm{Co}, \mathrm{Cu}, \mathrm{Fe}, \mathrm{Zn}, \mathrm{Ni}, \mathrm{Cd}, \mathrm{Mn}, \mathrm{Pb}, \mathrm{Cr}, \mathrm{As}$, Se, and $\mathrm{Bi}$ were determined by inductively coupled plasma optical emission spectrometry (Prodigy Teledyne, Leeman Labs) [27].

\section{Reagents}

The following reagents were used to perform the experimental work: $\mathrm{HCl}$ (37\% suprapur, Fluka), $\mathrm{HNO}_{3}$ (65\% suprapur, Merck), $\mathrm{H}_{2} \mathrm{SO}_{4}(98 \%$, pure for analys, Valrus) and Milli-Q water $(0,01 \mu \mathrm{S} / \mathrm{cm})$. 


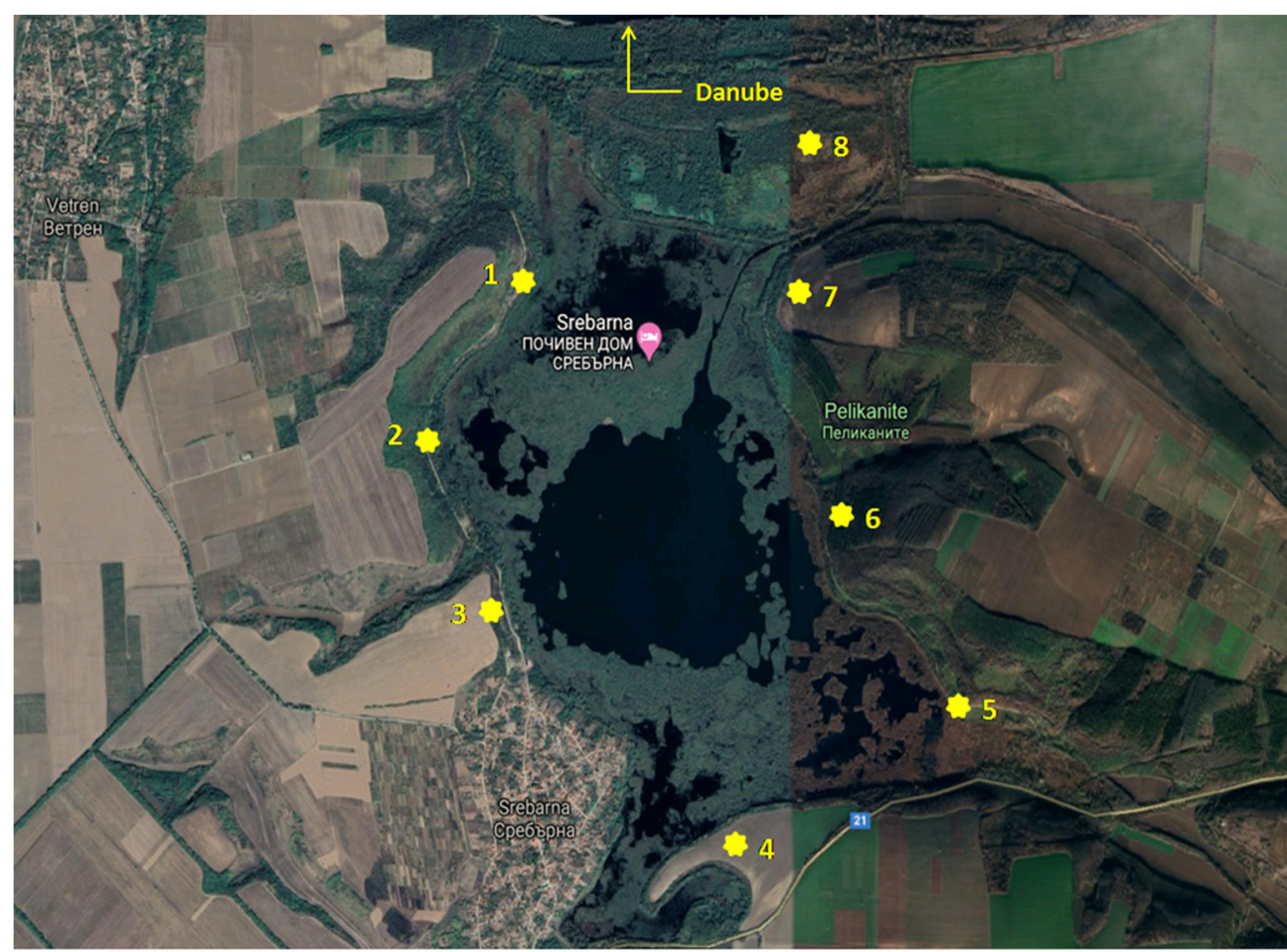

Figure 2. Map of the Srebarna Lake reserve with sampling points

\section{ACKNOWLEDGMENTS}

The authors would like to thank of Maria-Antoaneta Ivanova for the help for specifying the soil-sample points and the Science and Research Sector of the UCTM-Sofia for the financial support (Contract № 12019/2020).

\section{REFERENCES}

1. N. Petkov; Acrocephalus, 2006, 27 (128-129), 37-43.

2. N. Kamburova; T. Michev; J. Balk. Ecol., 2003, 6(2), 191-199.

3. M. Beshkova; R. Kalchev; L. Pechlivanov, V. Vassilev; Phytoplankton composition and abundance in Srebarna Lake and adjacent temporary wetlands (Bulgarian floodplain of the Lower Danube River), 2010, In: 38th IAD Conference, Dresden, Germany. 
4. G. Zhelezov; M. Varbanov; M. Germ; A. Gaberščik; Problems of Geography, 2011, 1-2, 107-118 (in Bulgarian).

5. M. Nikolova; R. Vatseva; V. Nikolov; GIS Assessment of Global Change Impacts on the Dynamics of the Srebarna Lake Ecosystem, 2010, In: 3rd International Conference on Cartography and GIS, 15-20 June, Nessebar, Bulgaria (in Bulgarian).

6. S. Nedialkov; H. Kochev; T. Michev; A. Damyanova; V. Velev; Contribution to the nesting distribution of the black kite Milvus migrans migrans (Boddaert, 1783) in Bulgaria, 1984, In: International Symposium "The role of wetlands in preserving the genetic material", Srebarna, 8-12 October, Collected works, BAS, Sofia, 164-187 (in Bulgarian).

7. V. Yanchev; I. Ivanova; R. Nedkov; J. Ecol. Eng. Env. Prot., 2011, 1, 4-11 (in Bulgarian).

8. A. Simeonova; J. Bekyarova; R. Chuturkova; J. Ecol. Eng. Env. Prot., 2011, 1, 25-30 (in Bulgarian).

9. C. Baoshan; Y. Qichun; Y. Zhifeng; Zh. Kejiang; Ecol. Engin., 2009, 35, 1090 1103.

10. K. Radeva; J. Ecol. Eng. Env. Prot., 2015, 4, 15-22 (in Bulgarian).

11. N. Pourang; Env. Monitor. Assess., 1995, 35, 207-219.

12. Q. Li; Z. Wu; B. Chu; N. Zhang; C. Cai; J. Fang; Environ. Pollut., 2007, 149, 158-164.

13. M. Khan; M. Khisroon; A. Khan; N. Gulfam; M. Siraj; F. Zaidi; A. Abidullah; S. Fatima; S. Noreen; Z. Shah; F. Qadir; BioMed. Research International, 2018, Article ID 1910274, 10 pages, https://doi.org/10.1155/2018/1910274.

14. G. Bonanno; J. Borg; V. Martino; Sci. Total Envir., 2017, 576, 796-806.

15. B. Chattopadhyay; A. Chatterjee; S. Mukhopadhyay; Aq. Ecosyst. Health \& Manag., 2002, 5(2), 191-203. DOI: $10.1080 / 14634980290031848$

16. K. Victor; M. Ladji; A. Adjiri; Y. Cyrille; T. Sanogo; Int. J. Chem. Tech. Research, 2016, 9(2), 189-195.

17. E. Belyoskii; Ecology of the bird in the impact regions, 2010, Dissertation, Ekaterinburg, Russia (in Russian).

18. C. Kwok; Y. Liang; H. Wang; Y. Dong; S. Leung; M. Wong; Ecotoxic. Environ. Safety, 2014, 106, 62-67.

19. State Gazette of Republic of Bulgaria, Regulation №3 of the Ministry of Environment and Water, the Ministry of Health and the Ministry of Agriculture and Food of Bulgaria from 1 august 2008 about the permissible norms for harmful substances in the soils. State Gazete, 71, 2008 (in Bulgarian).

20. Bulgarian National Standard (BNS) 17.4.5.01, 1985, Preservation of nature. Soil. General requirements for soil sampling (in Bulgarian).

21. BNS ISO 11464, 2012, Soil quality. Preliminary preparation of samples for physico-chemical analysis.

22. BNS EN 16174, 2012, Sediments, treated bio-wastes and soils. Solvation fractions and elements in "aqua regia". 
23. BNS EN 15933, 2012, Sediments, treated bio-wastes and soils. Dteremination of $\mathrm{pH}$.

24. BNS ISO 11265, 2002, Soil quality. Determination of the electric conductivity.

25. BNS ISO 11261, 2002, Quality of soils. Determination of total nitrogen. Modified method of Kjeldahl.

26. BG ISO 11263, 2002, Soil quality - Determination of phosphorus - Spectrometric determination of phosphorus soluble in sodium hydrogen carbonate solution.

27. BNS EN 16170, 2016, Sediments, treated bio-wastes and soils. Determination of elements through ICP-OES. 